Canadian

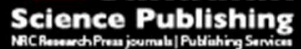

Canadian Journal of Forest Research Revue canadienne de recherche forestière

\title{
Phosphorus availability and fractionation vary among forest site types in reconstructed oil sands soils
}

\begin{tabular}{|r|l|}
\hline Journal: & Canadian Journal of Forest Research \\
\hline Manuscript ID & cjfr-2017-0169.R1 \\
\hline Manuscript Type: & Article \\
\hline Complete List of Authors: & $\begin{array}{l}\text { Wadu, Mihiri; University of Alberta } \\
\text { Duan, Min; University of Alberta, Department of Renewable Resources; } \\
\text { Shaanxi Sci-Tech University, Chemical \& Environmental Sciences } \\
\text { Chang, Scott; University of Alberta }\end{array}$ \\
\hline Keyword: & $\begin{array}{l}\text { phosphorus availability, reconstructed soils, tree growth, forest } \\
\text { productivity, phosphorus fractionation }\end{array}$ \\
\hline $\begin{array}{r}\text { Is the invited manuscript for } \\
\text { consideration in a Special } \\
\text { Issue? : }\end{array}$ & N/A \\
\hline
\end{tabular}


1 Phosphorus availability and fractionation vary among forest site types in

2 reconstructed oil sands soils

3

4 Mihiri C.W. Manimel Wadu, Min Duan, Scott X. Chang*

5

6442 Earth Sciences Building, Department of Renewable Resources, University of Alberta,

7 Edmonton, Alberta, Canada T6G 2E3

8

9 Text pages: 27 Tables: 3 Figures: 3

10 Supplementary tables: 2

11 Supplementary figures: 2

12

13 Submitted to: Canadian Journal of Forest Research

14

15 *Corresponding author. Tel.: +1 780 492-6375; Fax: +1 780 492-1767

16

17 E-mail address: manimelw@ualberta.ca / mihiri.wadu@gmail.com (M. Manimel Wadu),

18 mduan@snut.edu.cn (M. Duan), Scott.chang@ualberta.ca (S. X. Chang).

19 
20 Abstract: We investigated relationships between phosphorus (P) availability/fractionation and

21 growth of lodgepole pine (Pinus contorta) and white spruce (Picea glauca) in the Athabasca oil

22 sands region. The study sites had peat-mineral soil mix (PMM) as cover soil over a tailings

23 sand substrate planted to pine or an overburden substrate planted to spruce. Available P was

24 determined using a modified Kelowna extraction and sequentially extracted to obtain

25 exchangeable, Fe- and Al-bound, $\mathrm{Ca}$ - and Mg-bound, organic, and residual $\mathrm{P}$. The organic $\mathrm{P}$

26 content in PMM explained 83 and $65 \%$ of the variations in available $\mathrm{P}$ in the pine and spruce

27 sites, respectively. Phosphorus bound to Fe and Al in PMM was also positively related to

28 available $\mathrm{P}$ on pine sites $(p<0.001)$ but not on spruce sites. Available P in PMM was correlated

29 with aboveground biomass increment of spruce $(p<0.05)$ and explained $78 \%$ of the variation in

30 foliar P. Foliar P in both pine and spruce was lower than the adequate level for tree growth.

31 Low foliar P and available P in PMM affect the successful establishment of pine and spruce

32 trees on the reclaimed sites and proper $\mathrm{P}$ nutrition management is important to overcome $\mathrm{P}$

33 limitation in reclaimed soils.

36 Keywords: phosphorus availability, reconstructed soils, tree growth, forest productivity, 37 phosphorus fractionation 


\section{Introduction}

40

The Athabasca oil sands region (AOSR) in Alberta, Canada is the world's second largest reserve of recoverable oil (Humphries 2008). Reclamation of open-pit mines is a land rebuilding process aimed at creating ecosystems with land capability equivalent to or better than that existed pre-disturbance. Surface mining in the AOSR removes vegetation, surface and subsurface materials and therefore, the initial step in land reclamation is reconstructing the soil. Reconstructed soils usually have a capping material (cover soil) consisting of organic-rich soil that is placed over substrates (i.e., subsoil) such as tailings sand (TS) or overburden (OB) materials (Rowland et al. 2009). In past reclamation activities, peat-mineral soil mix (PMM) has commonly been used as the capping material. The PMM is a mixture of salvaged peat and surface mineral soils, while the TS is a by-product of the process that extracts bitumen from the oil sand, and all material that overlies the economically mineable oil sands is referred to as OB. Re-establishment of nutrient cycling, soil development, and vegetation growth play a critical role in restoring ecosystem functions on reconstructed soils (Macdonald et al. 2012), but properties of different substrates affect nutrient availability and root development in reconstructed soils in the AOSR (Jung et al. 2014; Jamro et al. 2015). Research has revealed that growth-limiting factors vary among different reclamation prescriptions and tree species growing on those sites; the growth of lodgepole pine (Pinus contorta var. latifolia) on PMM over TS was mainly affected by water availability while nitrogen $(\mathrm{N})$ availability, salinity and soil compaction affected the growth of white spruce (Picea glauca (Moench) Voss) on PMM over OB in reconstructed soils (Duan et al. 2015; Duan and Chang 2015). Moreover, changes in water and $\mathrm{N}$ availabilities cause variations in fine root biomass in TS profiles, while salinity and soil compaction affect fine root biomass in OB profiles (Jung et al. 2014; Jamro et al. 2015). 
63 Increased soil pH (Howat 2000) and high concentration of residual bitumen (Fung and Macyk

64 2000) can also negatively affect the growth of trees on reconstructed soils.

Phosphorus (P) as an essential macronutrient required by plants can be a limiting nutrient

66 in addition to N (Portsmuth et al. 2005; Nordin et al. 2001); however, few have studied the

67 implication of $\mathrm{P}$ availability for the establishment of vegetation on reclaimed sites. Oil sands

68 sites reclaimed with a peat-mineral capping soil require application of fertilizer $\mathrm{P}$ to provide an

69 early boost to ecosystem development (Rowland et al. 2009). Moreover, studies on germination

70 and initial growth of trembling aspen (Populus tremuloides) on contrasting oil sands

71 reclamation soils showed a positive relationship between P fertilization and tree growth (Pinno

72 et al. 2012). Available soil $\mathrm{P}$ varied with time in reclaimed plots with a peak at year 5 and then

73 declined to year 20 and available soil $\mathrm{P}$ in mature natural stands was approximately three times

74 greater than that in reclaimed stands at year 20 (Pinno and Hawkes 2015). In reclaimed soils

75 with TS comprising half or more of the soil profile to $1 \mathrm{~m}$, available $\mathrm{P}$ was significantly less

76 than that in the coarse natural analogues in the AOSR (Lanoue 2003). Low available P in

77 reclaimed soils suggests the necessity for conducting further research to identify factors

78 controlling $\mathrm{P}$ availability in these soils since low available $\mathrm{P}$ in soils can pose a long-term risk

79 on ecosystem development.

80 Phosphorus occurs in soil in a wide range of organic and inorganic compounds which

81 differ in their biological availability in the soil (Moazed et al. 2010) and the distribution of P

82 within chemically defined pools will ultimately determine the bioavailability, mobility and

83 mineralization of $\mathrm{P}$ in the soil (Dick and Tabatabai 1978; Liu et al. 2014). For instance, $\mathrm{P}$

84 fractions in soil may be characterized as the loosely adsorbed P, metal oxide bound P (i.e.,

85 mainly of $\mathrm{Fe}$ and $\mathrm{Al}$ ), $\mathrm{Ca}$ bound $\mathrm{P}$, and organic $\mathrm{P}$ that can be released through mineralization 
86 processes (Hedley et al. 1982). Most of the $\mathrm{P}$ in peat is bound to organic matter and as occluded

87 Fe, Al, and Ca phosphate (e.g., Nieminen and Jarva 1996; Nieminen and Penttilä 2004). Both

88 Fe-bound inorganic and organic $\mathrm{P}$ were also correlated with the stand volume growth on some

89 drained peat sites (Nieminen and Penttilä 2004). As such, soil P availability is extremely

90 complex and needs to be systematically evaluated due to the dynamic transformations of $\mathrm{P}$

91 between different pools; a comprehensive understanding of tree nutrition is not possible without

92 a better characterization of $\mathrm{P}$ in soils.

Considerable attention has been given to investigate $\mathrm{P}$ availability and fractionation in

94 reclaimed mine sites in different parts of the world. Phosphorus was a limiting factor in

95 restoring soil fertility on a newly reclaimed land after coal mining in China and dicalcium

96 phosphate was identified as the main source of variation in the capacity of soil to supply $\mathrm{P}$

97 (Chen et al. 1998). Some post-mining soils in northeast Germany were identified as P-deficient

98 and less $\mathrm{P}$ saturation in soils was coupled with rather small contents of oxalate extractable iron

99 and aluminum (Slazak and Freese 2015). In some reclaimed mine sites in the Appalachian

100 region, plant-available P (i.e., P measured using bicarbonate extraction) was $32 \%$ lower than in

101 a managed forest (Simmons and Currie 2005). These studies indicate that P limitation in

102 reclaimed soils is related to many different factors. However, $\mathrm{P}$ fractionation in reconstructed

103 soils in the AOSR has not been studied to the best of our knowledge. Therefore, there is a need

104 to determine the differences in $\mathrm{P}$ forms and $\mathrm{P}$ availability in soils constructed with different

105 reclamation prescriptions in the AOSR.

106 Changes in soil physical and chemical properties after reclamation would influence the

107 transformation of $\mathrm{P}$ and the distribution of $\mathrm{P}$ forms in the cover soil and substrate layers.

108 Organically bound $\mathrm{P}$ dominates the soil $\mathrm{P}$ pool in the humus layer and mineralization of $\mathrm{P}$ in the 
109

110

111

112

113

114

115

116

117

118

119

120

121

122

123

124

125

126

127

128

129

130

131

organic form is thus a major pathway for the release of plant-available $\mathrm{P}$ (Wood et al. 1984;

Cade-Menun et al. 2000). Phosphorus fixation is generally restricted to the mineral horizon due

to the accumulation of $\mathrm{Al}$ and $\mathrm{Fe}$ in this horizon (Wood et al. 1984; Li et al. 1999) and $\mathrm{P}$

fixation in soil is also dependent on soil $\mathrm{pH}$ (Sample et al. 1980). The ratio of peat to mineral

soil in the PMM cover soil ranges from pure peat to 60:40 depending on the site being

reclaimed in the AOSR (Pinno and Hawkes 2015). Thus, the proportions of organic and inorganic P in PMM may vary depending on the composition of PMM. Salinity and sodicity

can also affect $\mathrm{P}$ forms and $\mathrm{P}$ dynamics in reclaimed saline marsh soils and short-term $\mathrm{P}$

sorption by these soils was related to poorly crystalline Fe oxides, silicate clays, and Ca activity

in the soil solution (Domínguez et al. 2001). Also, varying concentrations of $\mathrm{Ca}, \mathrm{Mg}$ and $\mathrm{Al}$ in reconstructed soils (Jung et al. 2014) may determine the extent of P precipitation in PMM and substrate layers depending on the $\mathrm{pH}$ of different materials.

The goal of this study was to improve our understanding of $\mathrm{P}$ availability and forms in reconstructed soils and their relationship with foliar P concentration and tree growth of lodgepole pine and white spruce planted on PMM over TS and PMM over OB, respectively.

We hypothesized that $\mathrm{P}$ availability varies among different reclamation prescriptions due to varying soil properties associated with $\mathrm{PMM}, \mathrm{TS}$ and $\mathrm{OB}$, and that $\mathrm{P}$ fractionation would provide a comprehensive understanding of $\mathrm{P}$ availability in different reclamation materials. We further hypothesized that $\mathrm{P}$ availability in reconstructed soils is related to foliar $\mathrm{P}$ and ratios between foliar P and other nutrients to the extent that the growth of pine and spruce is affected. This study will provide information related to P fertility in reconstructed soils that can help improve the re-establishment of healthy ecosystems on reclaimed lands in the AOSR. 
132

133

134

135

136

137 forests and was characterized by a continental boreal climate having short, cool summers and 138

139

140

141

142

143

144 145

146

147

148

150

151

152

153

154

\section{Materials and Methods}

\subsection{Site description}

Study sites were located $22 \mathrm{~km}$ north of Fort McMurray $\left(56^{\circ} 59^{\prime} \mathrm{N}\right.$ and $\left.111^{\circ} 32^{\prime} \mathrm{W}\right)$ in northeastern Alberta, Canada. The study area was reclaimed from open-pit mining to upland long, cold winters. The mean annual temperature from 1971 to 2000 was $0.7^{\circ} \mathrm{C}$ with mean daily temperatures ranging from $-18.8^{\circ} \mathrm{C}$ (January) to $16.8^{\circ} \mathrm{C}$ (July). The mean annual precipitation for the same period was $456 \mathrm{~mm}$ with $342 \mathrm{~mm}$ occurring during the growing season (Environment Canada 2013).

The open-pit mine sites were re-constructed using PMM as the cover soil above reclamation substrates including TS and OB materials. Pine and spruce were planted on TS and OB sites, respectively. Details on site characteristics and understory plant communities are given elsewhere (Jung et al. 2014; Duan et al. 2015). Pine in different stands was planted in during 1991-1996, while spruce was planted during 1982-1992.

\subsection{Experimental design and soil sampling}

A total of eighteen sites, with nine pine sites and nine spruce sites were set up and soil samples were collected from PMM and the substrate in each site in July 2012. The top $20 \mathrm{~cm}$ of PMM and the upper $20 \mathrm{~cm}$ of substrates were collected using an auger in five randomly selected locations within each plot to obtain a composite PMM or substrate sample. The thickness of the PMM layer in pine and spruce sites ranged from 12 to $30 \mathrm{~cm}$ and 11 to $48 \mathrm{~cm}$, respectively (Duan et al. 2015). When the thickness of the PMM was less than $20 \mathrm{~cm}$, the entire 
155 PMM layer was sampled. Each soil sample was placed in a plastic bag immediately after

156 sampling, stored in a cooler and taken back to the laboratory. Upon returning to the laboratory,

157 a subsample of each soil sample was air-dried for chemical and physical analyses.

158

159

\subsection{Measurements of basic soil properties}

The gravimetric water content of each soil sample was measured after oven-drying a 161 subsample at $105^{\circ} \mathrm{C}$ for $24 \mathrm{~h}$. Soil texture was determined using the hydrometer method (Gee 162 and Or 2002). Soil $\mathrm{pH}$ was measured in deionized water using a digital DMP-2 mV/pH meter

163 (Thermo Fisher Scientific Inc., Waltham, MA) with a soil to water ratio of 1:2 (w:v). Mehlich

164 III extraction (Mehlich 1984) of soil samples was conducted as a measure of extractable cations 165 namely, $\mathrm{Ca}^{2+}, \mathrm{Mg}^{2+}, \mathrm{Fe}^{3+}$ and $\mathrm{Al}^{3+}$, which will be denoted as $\mathrm{Ca}_{\mathrm{M}}, \mathrm{Mg}_{\mathrm{M}}, \mathrm{Fe}_{\mathrm{M}}$, and $\mathrm{Al}_{\mathrm{M}}$ hereafter. 166 A $2.5 \mathrm{~g}$ of soil was placed in a centrifuged tube and $25 \mathrm{~mL}$ of Mehlich III solution $\left(0.2 \mathrm{~mol} \mathrm{~L}^{-1}\right.$

$167 \mathrm{CH}_{3} \mathrm{COOH}, 0.25 \mathrm{~mol} \mathrm{~L}^{-1} \mathrm{NH}_{4} \mathrm{NO}_{3}, 0.015 \mathrm{~mol} \mathrm{~L}^{-1} \mathrm{NH}_{4} \mathrm{~F}, 0.013 \mathrm{~mol} \mathrm{~L}^{-1} \mathrm{HNO}_{3}, 0.001 \mathrm{~mol} \mathrm{~L}^{-1}$

168 EDTA) was added. The mixture was then shaken for 5 min on a mechanical shaker at 120

169 strokes per min and the extract was filtered using a Whatman No. 40 filter paper. Cation

170 concentrations were measured using PerkinElmer Optima 3000 DV inductively coupled plasma

171 mass spectrometer (ICP-MS) (PerkinElmer Inc., Shelton, CT). Total C and N concentrations of

172 air-dried soil samples were measured with a Carlo Erba NA 1500 elemental analyzer (Carlo

173 Erba Instruments, Milano, Italy) at the Lethbridge Research Centre of Agriculture and Agri-

174 Food Canada (Duan et al. 2015).

175

$176 \quad$ 2.4. Soil $P$ extraction and fractionation 
Plant available $\mathrm{P}$ in soil samples was determined by the modified Kelowna method (Qian

178

179

180

181

182

183

184

185

186

187

188

189

190

et al. 1994), which is the most appropriate extractant for the determination of available $\mathrm{P}$ in natural and reclaimed soils in the AOSR (Lanoue 2003). The extraction was done by shaking $2.5 \mathrm{~g}$ of soil with $25 \mathrm{~mL}$ of the Kelowna reagent $\left(0.015 \mathrm{~mol} \mathrm{~L}^{-1} \mathrm{NH}_{4} \mathrm{~F}, 0.25 \mathrm{~mol} \mathrm{~L}^{-1}\right.$

$\mathrm{CH}_{3} \mathrm{COONH}_{4}$, and $0.25 \mathrm{~mol} \mathrm{~L}^{-1} \mathrm{CH}_{3} \mathrm{COOH}$ ) for 15 min on a mechanical shaker. The suspension was filtered and $\mathrm{P}$ in solution was determined colorimetrically by the molybdateascorbic acid method (Murphy and Riley 1962) using a scanning spectrophotometer (GENESYSTM 10 Series) at a wavelength of $882 \mathrm{~nm}$. As an estimation of the P adsorption maxima $\left(\mathrm{P}_{150}\right)$, a single point adsorption experiment was conducted at $150 \mathrm{mg} \mathrm{P} \mathrm{L}{ }^{-1}$ concentration (Ige et al. 2005). Two grams of air-dried soil were weighed into a $50 \mathrm{~mL}$ centrifuge tube and $20 \mathrm{~mL}$ of $\mathrm{P}$ solution in $0.01 \mathrm{~mol} \mathrm{~L}^{-1} \mathrm{KCl}$ was added. Two drops of toluene were added to inhibit microbial activity and the suspension was shaken for 24 hours on a mechanical shaker at room temperature and then centrifuged at $3000 \times \mathrm{g}$ for $10 \mathrm{~min}$ and filtered through a $0.45 \mu \mathrm{m}$ syringe filter. Phosphorus concentrations in the solution were determined colorimetrically using the scanning spectrophotometer at a wavelength of $882 \mathrm{~nm}$.

Sequential extraction of $\mathrm{P}$ was conducted according to the modified method of Nair et al. (1995) to distinguish five forms of $\mathrm{P}$, with the extractants listed in parentheses: exchangeable (1 mol L $\left.{ }^{-1} \mathrm{NH}_{4} \mathrm{Cl}\right), \mathrm{Fe}$ - and Al-bound $\left(0.1 \mathrm{~mol} \mathrm{~L}^{-1} \mathrm{NaOH}\right), \mathrm{Ca}$ - and $\mathrm{Mg}$-bound $\left(0.5 \mathrm{~mol} \mathrm{~L}^{-1} \mathrm{HCl}\right)$, organic (see below for definition), and residual P. Phosphorus fractions extracted by different extractants will be abbreviated as follows: Ex-P, exchangeable or easily removable P; Fe/Al-P, $\mathrm{P}$ associated with Fe and $\mathrm{Al}$; Org-P, organically bound $\mathrm{P}$; $\mathrm{Ca} / \mathrm{Mg}-\mathrm{P}, \mathrm{Ca}$ and $\mathrm{Mg}$ associated $\mathrm{P}$. Inorganic $\mathrm{P}$ in various soil extracts and digests was determined colorimetrically using the molybdate- ascorbic acid method. The difference between the total amount of $\mathrm{P}$ in the digested 
$200 \mathrm{NaOH}$ extract and the amount of inorganic $\mathrm{P}$ detected in undigested $\mathrm{NaOH}$ extract was taken as

201 the amount of organic $\mathrm{P}$ present. Total $\mathrm{P}$ in the soil was determined after Kjeldahl digestion

$202\left(\mathrm{HClO}_{3}\right.$ and $\mathrm{HNO}_{3}$ acid digestion) of soil samples (Sparks et al. 1996) and $\mathrm{P}$ was measured

203 colorimetrically using the molybdate-ascorbic acid method. The sum of Ex-P, Fe/Al-P, Org-P

204 and $\mathrm{Ca} / \mathrm{Mg}-\mathrm{P}$ will be referred to as the total extractable $\mathrm{P}$ fraction. Residual $\mathrm{P}$ was calculated as

205 the difference between total $\mathrm{P}$ and the total extractable $\mathrm{P}$ determined by the fractionation

206 method.

207

208

\subsection{Measurement of tree growth parameters and foliar $P$ analysis}

On each site, a 10 x $10 \mathrm{~m}$ plot was set up for soil and plant sampling and measurement of

210 tree growth. Tree size was measured in September 2011 and 2012 for twelve sites and the rest

211 in May and September 2012 assuming that there was minimal growth during the winter season.

212 Tree height and diameter at breast height (1.3 $\mathrm{m}$ above the ground) of all trees within each plot

213 were measured using a height pole and a diameter tape, respectively. Aboveground biomass of

214 trees of each site was calculated using the diameter at breast height and height-based allometric

215 equations (Lambert et al. 2005; Ung et al. 2008). The difference of aboveground biomass of

216 trees between two measurement intervals was calculated as the current annual increment of

217 aboveground biomass (ABI). In addition, annual aboveground biomass increment based on tree

218 age and the growth measured over one year (current year) were significantly correlated $\left(\mathrm{R}^{2}=\right.$

$2190.55 ; p<0.05)$, Supplementary Figure S1). But only the ABI based on the current year

220 measurements was considered as the most accurate measure of current stand growth in young

221 stands. In October 2012, five trees were randomly selected in each plot, and one branch from

222 the upper one-third of the live crown of each tree was collected to form a composite branch 
223 sample for each plot. Branch samples were placed in paper bags and taken back to the

224 laboratory. The foliage from each branch was separated into current-year and 1-year-old

225 needles. After washing twice with distilled water, needles were oven-dried at $65^{\circ} \mathrm{C}$ for $24 \mathrm{~h}$ or

226 until constant weight. Three hundred needles were randomly selected and weighed to determine

227 the unit needle weight. The sample was subsequently ground to pass through a $0.15 \mathrm{~mm}$ sieve

228 in preparation for nutrient analyses. The total $\mathrm{P}$ and micronutrients $(\mathrm{Fe}, \mathrm{Mn}, \mathrm{Zn}, \mathrm{Cu}$ and $\mathrm{B})$ in

229 needles were analyzed by ICP-MS after digestion using concentrated $\mathrm{HNO}_{3}$ and $30 \% \mathrm{H}_{2} \mathrm{O}_{2}$ on a

230 digestion block at $125^{\circ} \mathrm{C}$ for $4 \mathrm{~h}$ (Campbell and Plank 1998). Concentration of total $\mathrm{N}$ in

231 needles was determined with a Carlo Erba NA 1500 elemental analyzer (Carlo Erba

232 Instruments, Milano, Italy).

233

$234 \quad$ 2.6. Statistical analysis

235 All statistical analyses of soil and plant measurements were performed by tree species

236 since the two species were planted on different substrates and the term 'site type' will be used

237 to indicate the specific tree species and substrate combinations hereafter. As such, the purpose

238 of the following statistical analyses was to identify relationships within a particular site type but

239 not to compare between site types. Pearson correlation analyses between foliar P concentration,

240 soil properties, and $\mathrm{P}$ fractions in PMM were performed. The absolute concentrations of soil P

241 fractions $\left(\mathrm{mg} \mathrm{kg}^{-1}\right)$ were included in the correlation analysis. Linear regression analysis was

242 conducted between available soil P, soil P fractions and foliar P for both pine and spruce. An $\alpha$

243 value of 0.05 was chosen to indicate statistical significance in all analyses except for the

244 correlation analysis between ABI and soil and foliar parameters for spruce sites where an $\alpha$

245 value of 0.10 was considered. The large $\alpha$ value of 0.1 was selected to identify any possible 
246 relationship between $\mathrm{ABI}$ and soil and foliar nutrient parameters in spruce sites. Tree

247 establishment at different times has caused a large variability in ABI data and detecting

248 significant correlations between ABI and other parameters were not possible at a lower $\alpha$ value.

249 All statistical analyses were conducted using the SAS software (SAS 9.2, SAS Institute Inc.,

250 Cary, NC).

251

252 3. Results

253

254 3.1. Soil properties, available $\mathbf{P}$ and $\mathbf{P}$ fractionation in pine sites

255 Large differences in soil properties were found between PMM and TS with regards to $\mathrm{pH}$, 256 organic matter content, clay content and extractable cations (Table 1). The highest available P

257 was found in the PMM layer $\left(1.9 \mathrm{mg} \mathrm{kg}^{-1}\right)$ in the pine sites which was more than 4-fold greater 258 than that in the TS (Table 1). Around 30 and 50\% of total $\mathrm{P}$ was extracted during the sequential 259 P fractionation in PMM and TS, respectively (Fig. 1a). High concentrations of Org-P and 260 Fe/Al-P fractions were found in both PMM and TS (Fig. 1b). Although the largest Org-P 261 fraction (\%) among all samples was found in TS (Fig. 1a), the Org-P concentration was about 4 262 and $16 \mathrm{mg} \mathrm{kg}^{-1}$ in TS and PMM, respectively (Fig. 1b).

263 In PMM, Ex-P, Fe/Al-P, and Org-P were all positively correlated with available P (Table 264 2). A significant correlation was found only between Fe/Al-P and Org-P among all the P 265 fractions measured in PMM in pine sites. Both Mehlich extractable $\mathrm{Ca}$ and Fe were related to $\mathrm{P}$ 266 sorption in PMM of pine sites as shown by the positive correlations between $\mathrm{P}_{150}$ and $\mathrm{Ca}_{\mathrm{M}}$ and $267 \mathrm{Fe}_{\mathrm{M}}$. Mehlich extractable Al was significantly correlated with Org-P and available P, while $\mathrm{Fe}_{\mathrm{M}}$ 268 was negatively correlated with available P. Both Org-P and Fe/Al-P were negatively correlated 
269 with pH in PMM (Table 2). Moreover, Org-P and Fe/Al-P explained 83 and 86\%, respectively, 270 of the variation in available P in PMM (Fig. 2).

271

$272 \quad 3.2$ Soil properties, available $P$ and $P$ fractionation in spruce sites

Among soil parameters only bulk density, $\mathrm{EC}$, organic matter content and $\mathrm{Al}_{\mathrm{M}}$ were

274 different between PMM and OB (Table 1). Both available P and total P concentrations were not

275 significantly different between $\mathrm{PMM}$ and $\mathrm{OB}$. Total extractable $\mathrm{P}$ in $\mathrm{OB}$ was twice as much as

276 that in PMM (Fig. 1a). A characteristic feature is the highest $\mathrm{Ca} / \mathrm{Mg}-\mathrm{P}$ concentration in $\mathrm{OB}$ as

277 compared to PMM and the greater Org-P concentration in PMM as compared to OB (Fig.1b).

278

279 (Table 2). Available $\mathrm{P}$ and Org-P, $\mathrm{Mg}_{\mathrm{M}}, \mathrm{Al}_{\mathrm{M}}, \mathrm{Fe}_{\mathrm{M}}, \mathrm{P}_{150}$ and organic matter content in PMM

280 were significantly correlated. Both $\mathrm{Mg}_{\mathrm{M}}$ and $\mathrm{Fe}_{\mathrm{M}}$ were positively correlated with Org-P but not

281 with $\mathrm{Al}_{\mathrm{M}}$ in PMM. In contrast to the pine sites, a positive correlation between available $\mathrm{P}$ and

$282 \mathrm{P}_{150}$ in PMM was noted for spruce sites. In PMM, Org-P explained $65 \%$ of the variation in

283 available $\mathrm{P}$ although Fe/Al-P did not have a significant relationship with available P in PMM

284 (Fig. 2).

285

286

287

288

\subsection{Relationships between available $P$, foliar $P$ and tree growth in pine sites}

Foliar $\mathrm{P}$ concentration in pine varied in a narrow range from 1.1 to $1.3 \mathrm{mg} \mathrm{kg}^{-1}$ with a

289 foliar N:P ratio of $12 \pm 0.7$ (Table 1). Foliar P concentrations in current and one-year-old

290 needles were not significantly different (Fig. 3a). There was no significant relationship between

291 ABI and available P in either PMM or TS in the pine sites (Supplementary Table S3). However, 
292 foliar P in current-year needles was related to soil available P in PMM in the pine sites (Fig. 293 3b), with foliar P concentration showed a tendency to decrease when available P was greater

294 than $\sim 3.5 \mathrm{mg} \mathrm{kg}^{-1}$ in PMM. Among different $\mathrm{P}$ fractions, only $\mathrm{Ca} / \mathrm{Mg}-\mathrm{P}$ and $\mathrm{ABI}$ were strongly 295 correlated in the pine sites $(r=-0.67, \mathrm{p}<0.05)$.

296

297 3.4. Relationships between available $P$, foliar $P$ and tree growth in spruce sites

Foliar P concentration in the current-year needles of spruce varied from 0.9 to $1.9 \mathrm{mg} \mathrm{kg}^{-}$

$299{ }^{1}$, and the foliar N:P ratio was $9 \pm 2.2$ (Table 1). The available P in OB was not related with 300 either foliar P or ABI (Supplementary Table S4). Available P in PMM in spruce sites explained $30178 \%$ of the variation in current-year foliar P concentration (Fig. 3b). In contrast with the pine 302 sites, there was a significant correlation between ABI and foliar P concentration in current-year 303 needles (Table 3). Also, the ratios between $\mathrm{P}$ and Fe, Mn and $\mathrm{Zn}$ in spruce needles were 304 positively and significantly correlated with ABI (Table 3 ), but none of the $\mathrm{P}$ fractions was 305 correlated with ABI.

\section{Discussion}

\section{1. $P$ availability and fractionation varied in pine and spruce sites}

The detailed analysis of different soil $\mathrm{P}$ forms provides insights into $\mathrm{P}$ availability in

311 reconstructed soils. The difference in P fractions between the PMM and substrates in this study

312 supports the hypothesis that varying soil properties caused differences in $\mathrm{P}$ fractionation and

313 availability among PMM, TS, and OB. Since Org-P and Fe/Al-P were related to P availability

314 in the studied soils (Fig. 2), the pathways for supplying P into the available P pool can be Org-P 
315 mineralization (Adams and Pate 1992), dissolution of inorganic Fe/Al-P, and dissolution of 316 amorphous Al- and Fe-organic matter coatings that contain occluded P (Fox and Comerford 317 1990). Relationships between available P and Org-P in PMM (Fig. 2) in both site types were 318 different despite having similar Org-P concentrations (Fig 1a) due to the varying degrees of P 319 retention by the Org-P (Table 2).

320 The weak relationship between available $\mathrm{P}$ and Fe/Al-P in the spruce compared to the 321 pine sites is not surprising since different Fe/Al oxides (i.e., amorphous and crystalline Fe/Al 322 oxides) (Mahieu et al. 2000) exhibit varying P adsorption capacities (Arai and Livi 2005; Arai 323 et al. 2013). Negatively charged P compounds attach themselves to hydrous Fe or Al oxides 324 (Turner et al. 2005) and thereby could turn a large proportion of soil P into unavailable forms 325 (Arai and Livi 2013; Solomon and Lehmann 2000). On the other hand, the presence of organic 326 327 enhancing the availability of $\mathrm{P}$ in Fe/Al-P fraction as in the pine sites (Fig. 2). Formation of 328 sparingly soluble $\mathrm{Ca} / \mathrm{Mg}$-P reduces $\mathrm{P}$ availability when the $\mathrm{Ca}$ concentration and $\mathrm{pH}$ is high in 329 soils (Sample et al. 1980), similar to that in most pine and spruce sites (Table 1). Surprisingly, a 330 direct relationship between $\mathrm{Ca} / \mathrm{Mg}-\mathrm{P}$ and available $\mathrm{P}$ was not found in this study. The Org-P mineralization may be important phenomena in pine and spruce sites due to 332 the marked influence of Org-P on available P. Although the total P in PMM is high (Table 1), 333 mineralization into the available form was small as evident by the large differences between 334 Org-P and available P in PMM (Table 1, Fig. 2). The mineralization of Org-P can be influenced 335 by the different $\mathrm{C}: \mathrm{P}$ and $\mathrm{C}: \mathrm{N}$ ratios in $\mathrm{PMM}$ in the two site types (Table 1). A greater 336 immobilization of $\mathrm{P}$ results in lower available $\mathrm{P}$ in sites with a high $\mathrm{C}: \mathrm{P}$ ratio, which ranges 337 from 112 to 501 (Stevenson 1986; Enwezor 1976). The ratio between total $\mathrm{N}$ and $\mathrm{P}$ in PMM 
338 was about four- or five-fold higher than that in tree foliage in some spruce sites (Supplementary

339 Figure S2) and when $\mathrm{N}$ and $\mathrm{P}$ are released by microbial mineralization (Alexander 1967), it 340 often results in a shortage of available $\mathrm{P}$ relative to the available $\mathrm{N}$ leading to $\mathrm{P}$ limitation for 341 tree growth.

\subsection{Low foliar $P$ in pine and spruce and the need for $P$ fertilization in reclaimed sites}

Foliar P concentration was lower than the adequate level needed for lodgepole pine

345 (adequate when foliar P $>1.5 \mathrm{mg} \mathrm{g}^{-1}$; Carter 1992) but none of the pine sites had a foliar P level

346 (Fig. 3a) that indicates severe P deficiency ( $<0.9 \mathrm{mg} \mathrm{g}^{-1}$; Carter 1992) when compared with the

347 thresholds that establish P deficiency. The foliar N:P ratio of pine sites was greater than the

348 threshold value of 11 indicating slight to moderate P deficiency (Brockley 2001) where foliar N

349 concentration $\left(>13.5 \mathrm{mg} \mathrm{kg}^{-1}\right)$ was greater than the deficiency level for pine (Brockley 2001).

350 Therefore, the foliar $\mathrm{P}$ and $\mathrm{N}: \mathrm{P}$ ratio corroborate with each other to indicate moderate $\mathrm{P}$

351 deficiency in the pine sites. Pine is less sensitive to soil nutrient deficiencies than spruce (Périé

352 and Munson 2000; Bothwell et al. 2001) and often succeed in nutrient-poor soils (Weetman et

353 al. 1985). Therefore, the absence of a relationship between foliar P and ABI in pine is possible

354 even with low foliar $\mathrm{P}$ and the imbalance between foliar $\mathrm{P}$ and $\mathrm{N}$ concentrations

355 (Supplementary Table S3).

Foliar P in pine needles did not increase with increasing available P in PMM (Fig. 3b),

357 suggesting that other factors control foliar P in pine sites. Nutrient supply for trees is not only

358 determined by the concentrations of available nutrients in the soil but also by the nutrient

359 uptake kinetics of their (mycorrhizal) roots (Bassirirad et al. 1999). Phosphorus concentrations

360 decreased in above- and belowground tissues in trees under low water availability in the soil 
361 (Peuke and Rennenberg 2004). Therefore, low water availability in pine sites (Duan et al. 2015)

362 may be the reason for low foliar P concentration when the concentration of soil available $\mathrm{P}$ was

363 high (Fig. 3b). Further research is needed to investigate underlying mechanisms for low foliar P

364 in pine regardless the high available $\mathrm{P}$ in the soil. Although very low $\mathrm{P}$ concentration in TS can 365 reduce the capacity of the soil to supply $\mathrm{P}$ for pine growth (Fig. 1), neither available P nor P 366 fractions in TS were significantly correlated with ABI (Supplementary Table S3).

367 The foliar P concentration in spruce was also lower than the adequate $\mathrm{P}$ concentration 368 (adequate when foliar P $>1.6 \mathrm{mg} \mathrm{g}^{-1}$; Carter 1992) for tree growth. Most of the sites (Fig. 3a) 369 showed some level of P deficiency when compared with the thresholds established in the 370 literature (Carter 1992) and the growth of spruce was significantly related to available P in 371 PMM (Table 3). The foliar N:P ratio of spruce was below the critical value of 11 reported for 372 trees in natural upland ecosystems (Tessier and Raynal 2003). The low foliar N concentration 373 (i.e., $<14.5 \mathrm{mg} \mathrm{g}^{-1}$, Carter 1992) in spruce indicates that both $\mathrm{N}$ and $\mathrm{P}$ limitations had caused the 374 low foliar N:P ratio. In addition, foliar P:Fe, P:Mn and P:Zn ratios were significantly and 375 positively related with ABI (Table 3). Since foliar Fe, Mn and Zn concentrations (Table 1) in 376 spruce were present at adequate levels (Carter 1992), the low nutrient ratios was caused by low 377 foliar P concentrations causing adverse effects on ABI. Similar to our result, strong 378 relationships between available $\mathrm{P}$ and site productivity (based on site index) of white spruce 379 have been reported in other studies (Harding 1985; Wang 1995).

380 Increasing foliar $\mathrm{P}$ is beneficial for improving the balance between $\mathrm{P}$ and micronutrients 381 in spruce trees and white spruce is generally a more nutrient-demanding coniferous species that 382 requires a higher concentration of $\mathrm{P}$ than other boreal coniferous species (Wilde 1966), 383 including pine species (Ingestad 1979). Improving P fertility would be essential for enhancing 
384 the long-term productivity of spruce stands and nutrient content in current-year needles of 385 spruce was sensitive to fertilization (Munson et al. 1994). Thus fertilizer trials to determine P 386 application rate to ensure adequate supply of $\mathrm{P}$ and other nutrients in spruce sites with OB 387 substrate are essential to achieve sustainable land reclamation. Attention should also be paid to 388 the need for long-term P fertility management in spruce sites by monitoring available P in soil 389 and foliar P levels after fertilizer application to determine the effectiveness of $\mathrm{P}$ application. 390 Additional research is clearly needed to further elucidate the mechanisms controlling P uptake 391 in pine sites in light of the low foliar P measured in those sites with high available P in PMM. 392

\section{Conclusions}

Both the lodgepole pine and white spruce stands we studied had below optimum levels of 395 foliar $\mathrm{P}$ concentrations, with foliar $\mathrm{N}$ and $\mathrm{P}$ ratios imbalanced in pine trees. Our results 396 demonstrated that there was no relationship between foliar P and tree growth rate in the pine 397 sites and the main limitation was with other growth factors such as water availability while P 398 was a limitation for the growth of trees on the spruce sites. Phosphorus availability varied 399 between the two site types owing to the variations in P fractionations. Low P availability is a 400 risk for long-term ecosystem development on some reconstructed sites in the AOSR and could 401 especially be a concern with planting nutrient demanding species such as white spruce on such 402 reclaimed soils. Phosphorus fertilization would be required to achieve better growth

403 performance in newly established ecosystems. Also, regular monitoring of soil P availability in 404 soil and foliar P levels is essential due to the potential for some reclamation materials to lower 405 the availability of $\mathrm{P}$ after it has been applied to reclaimed sites. While a direct comparison 406 between the two site types is not possible due to the confounding of tree species and substrate 
407 type effects, further research is needed to separate the tree species vs. soil substrate effect on 408 soil P availability and tree growth to improve the management of reconstructed soils in the oil 409 sands.

\section{Acknowledgements}

413 This study was supported by the Discovery program of the Natural Science and Engineering

414 Council of Canada (NSERC) and the Land Reclamation International Graduate School

415 (LRIGS), which was funded by a Collaborative Research and Training Experience (CREATE)

416 grant from the NSERC. Suncor Energy provided logistic support. We also thank Jason House

417 and others in the Forest Soils Laboratory for assistance in conducting the fieldwork.

\section{References}

420

421 Adams, M. A., and Pate, J. S. 1992. Availability of organic and inorganic forms of phosphorus to lupins (Lupinus spp.). Plant Soil 145: 107-113.

423 Alexander, M. 1967. Introduction to Soil Microbiology, 4th ed. John Wiley \& Sons, New York. $424 \quad 472 \mathrm{p}$.

425 Arai, Y. and Livi, K. J. 2013. Underassessed phosphorus fixation mechanisms in soil sand 426 fraction. Geoderma 192: 422-429.

427 Arai, Y., Livi, K. J. T., and Sparks, D. L. 2005. Phosphate reactivity in long-term poultry litteramended southern Delaware sandy soils. Soil Sci. Soc. Am. J. 69: 616-629.

429 Bassirirad, H., Prior, S., Norby, R., and Rogers, H. 1999. A field method of determining $\mathrm{NH}_{4}^{+}$ 
and $\mathrm{NO}_{3}{ }^{-}$uptake kinetics in intact roots: effects of $\mathrm{CO}_{2}$ enrichment on trees and crop species. Plant Soil 217: 195-204.

Bothwell, K. S., Prescott, C. E., and Jones, M. D. 2001. Factors contributing to the superior growth and N nutrition of 11-year-old lodgepole pine compared with Sitka spruce on a N-poor cedar-hemlock cutover. Can. J. For. Res. 31: 1272-1279.

Brockley, R. P. 2001. Foliar sampling guidelines and nutrient interpretative criteria for lodgepole pine. B.C. Min. For., Victoria, B.C. Extension Note 52.

Cade-Menun, B. J., Berch, S. M., Preston, C. M., and Lavkulich, L. M. 2000. Phosphorus forms and related soil chemistry of Podzolic soils on northern Vancouver Island. I. A comparison of two forest types. Can. J. For. Res. 30: 1714-1725.

Campbell, C. R., and Plank, C. O. 1998. Preparation of plant tissue for laboratory analysis. In Handbook of Reference Methods for Plant Analysis. Edited by Y. P. Kalra. CRC Press, Boca Raton, Florida, pp. 37-50.

Carter, R. 1992. Diagnosis and interpretation of forest stand nutrient status. In Forest Fertilization: sustaining and improving nutrition and growth of western forests. Edited by H. N. Chappell, G. F. Weetman, and R. E. Miller. College of Forest Resources, University of Washington, Seattle, Wash, Contribution No. 73. pp. 7-90.

Chen, H., Zheng, C., and Zhu, Y. 1998. Phosphorus: A limiting factor for restoration of soil fertility in a newly reclaimed coal mined site in Xuzhou, China. Land Degrad. Develop. 9: $115-121$.

Dick, W. A., and Tabatabai, M. A. 1978. Hydrolysis of organic and inorganic phosphorus compounds added to soils. Geoderma 21: 175-182.

Domínguez, R., Del Campillo, C., Pena F., and Delgado, A. 2001. Effect of soil properties and 
reclamation practices on phosphorus dynamics in reclaimed calcareous marsh soils from the Guadalquivir valley. SW Spain. Arid Land Res. Manage. 15: 203-221.

Duan, M., and Chang, S. X. 2015. Responses of lodgepole pine (Pinus contorta) and white spruce (Picea glauca) to fertilization in some reconstructed boreal forest soils in the oil sands region. Ecol. Eng. 84: 354-361.

Duan, M., House, J., and Chang, S. X. 2015. Limiting factors for lodgepole pine (Pinus contorta) and white spruce (Picea glauca) growth differ in some reconstructed sites in the Athabasca oil sands region. Ecol. Eng. 75: 323-331.

Environment Canada, 2012. National climate data and information archive. http://climate.weatheroffice.gc.ca/climate normals/results e.html Province $=$ ALTA\&StationName $=\&$ SearchType $=\&$ LocateBy $=$ Province $\&$ Proximit $\mathrm{y}=25 \&$ ProximityFrom $=$ City $\&$ StationNumber $=\&$ IDType $=$ MSC $\&$ CityName $=\&$ ParkNam $\mathrm{e}=\&$ LatitudeDegrees $=\&$ LatitudeMinutes $=\&$ LongitudeDegrees $=\&$ LongitudeMinutes $=\&$ NormalsClass $=$ A\&SelNormals $=\& \operatorname{StnId}=2519 \&$ autofwd $=020111 / 22$.

Enwezor, W. O. 1976. The mineralization of nitrogen and phosphorus in organic materials of varying C:N and C:P ratios. Plant Soil. 44: 237-24.

Fox, T. R. 1995. The influence of low molecular weight organic acids on properties and processes in forest soils. In Carbon Forms and Functions in Forest Soils. Edited by W. W. McFee and J. M. Kelly. SSSA, Madison, Wisconsin, pp 43-61.

Fox, T. R., and Comerford, N. B. 1990. Low-molecular-weight organic acids in selected forest soils of the southeastern USA. Soil Sci. Soc. Am. J. 54: 1139-1144. 
474 Fung, M. Y. P., and Macyk, T. M. 2000. Reclamation of oil sands mining areas. In Reclamation

475

476

477

478

479

480

481

482

483

484

485

486

487

488

489

490

491

492

493

494

495

496

of Drastically Disturbed Lands. Edited by R. I. Barnhisel, R. G. Darmody, and W. L. Daniels. ASA, CSSA and SSSA, Madison, Wisconsin, pp. 755-774.

Gee, G. W., and Or, D. 2002. Particle size analysis. In Methods of Soil Analysis Part 4: Physical Methods. Edited by J. H. Dane and G. C. Topp. SSSA, Madison, Wisconsin, pp. 255-293.

Harding, R. B., Grigal, D. F., and White, E. H. 1985. Site quality evaluation for white spruce plantations using discriminant analysis. Soil Sci. Soc. Am. J. 49: 229-232.

Hedley, M. J., Stewart, J. W. B., and Chauhan, B. S. 1982. Changes in inorganic and organic soil phosphorus fractions by cultivation practices and by laboratory incubations. Soil Sci. Soc. Am. J. 46: 970-976.

Howat, D. R. 2000. Acceptable salinity, sodicity and pH Values for boreal forest reclamation. Alberta Environment, Edmonton, Alberta.

Humphries, M. 2008. North American oil sands: History of development, prospects for the future. Congressional Research Service.

Ige D. V., Akinremi, O. O., Flaten, D. N., Ajiboye, B., and Kashem, M. A. 2005. Phosphorus sorption capacity of alkaline Manitoba soils and its relationship to soil properties. Can. J. Soil Sci. 85: 417-426.

Ingestad, T. 1979. Mineral nutrient requirements of Pinus sylvestris and Picea abies seedlings. Physiol. Plant. 45: 373-380.

Jamro, G. M., Chang, S. X., Naeth, M. A., Duan, M., and House, J. 2015. Fine root dynamics in lodgepole pine and white spruce stands along productivity gradients in reclaimed oil sands sites. Ecol. Evol. 5: 4655-4670. 
497 Jones, D. L., and Darrah, P. H. 1994. Role of root derived organic acids in the mobilization of 498 nutrients from the rhizosphere. Plant Soil 166: 247-257.

499 Jung, K., Duan, M., House, J., and Chang, S. X. 2014. Textural interfaces affected the 500 distribution of roots water, and nutrients in some reconstructed forest soils in the $501 \quad$ Athabasca oil sands region. Ecol. Eng. 64: 240-249.

502 Lambert, M. C., Ung, C. H., and Raulier, F. 2005. Canadian national tree aboveground biomass 503 equations. Can. J. For. Res. 35: 1996-2018.

504

505

506

507

508

509

510

511

512

513

514

515

516

517

518

519

Lanoue, A. V. L. 2003. Phosphorus content and accumulation of carbon and nitrogen in boreal forest soils. MSc thesis. University of Alberta. Edmonton, Alberta, Canada.

Li, Y. C., Alva, A. K., and Calvert, D. V. 1999. Transport of phosphorus and fractionation of residual phosphorus in various horizons of a Spodosol. Water Air Soil Pollut. 109: 30312.

Liu, J., Yang, J., Liang, X., Zhao, Y., Cade-Menun, B. J., and Hu, Y. 2014. Molecular speciation of phosphorus present in readily dispersible colloids from agricultural soils. Soil Sci. Soc. Am. J. 78: 47-53.

Macdonald, S. E., Quideau, S. A., and Landhäusser, S. M., 2012. Rebuilding boreal forest ecosystems after industrial disturbance. In Restoration and Reclamation of Boreal Ecosystems: Attaining Sustainable Development. Edited by D. H. Vitt and J. S. Bhatti. Cambridge University Press.

Mahieu, N., Olk, D. C., and Randall, E. W. 2000. Analysis of phosphorus in two humic acid fractions of intensively cropped lowland rice soils by ${ }^{31}$ P-NMR. Eur. J. Soil Sci. 51: 391-402.

Mehlich, A. 1984. Mehlich 3 Soil Test Extractant: A Modification of Mehlich 2 Extractant. 
Comm. Soil Sci. Plant Anal. 15: 1409-1416.

521 Moazed, H., Hoseini, Y., Naseri, A. A., and Abbasi, F. 2010. Determining phosphorus adsorption isotherm in soil and its relation to soil characteristics. Int. J. Soil Sci. 5: 131-139.

523 Munson, A. D., Margolis, H. A., and Brand, G. B. 1994. Seasonal nutrient dynamics in white pine 524 and white spruce in response to environmental manipulation. Tree Physiol. 15: 141-149.

525 Murphy, J., and Riley, J. P. 1962. A modified single solution methods for the determination of 526 phosphate in natural water. Anal. Acta. 27: 31-36.

527 Nair, V. D., Graetz, D. A., and Portier, K. M. 1995. Forms of phosphorus in soil profiles from 528 dairies of south Florida. Soil Sci. Soc. Am. J. 59: 1244-1249.

529 Nieminen, M. and Jarva, M. 1996. Phosphorus adsorption by peat from drained mires in $530 \quad$ southern Finland. Scand. J. Forest Res. 11: 321-326.

531 Nieminen, M., and Penttilä, T. 2004. Inorganic and organic phosphorus fractions in peat from drained mires in northern Finland. Silva Fenn. 38: 243-251.

533 Nordin, A., Hogberg, P., and Nasholm, T. 2001. Soil nitrogen form and plant nitrogen uptake along a boreal forest productivity gradient. Oecologia 129: 125-132.

535 Périé, C., and Munson A. D. 2000. Ten-year responses of soil quality and conifer growth to 536 silvicultural treatments. Soil Sci. Soc. Am. J. 64: 1815-1826.

537 Peuke, A., and H. Rennenberg. 2004. Carbon, nitrogen, phosphorus, and sulphur concentration 538 and partitioning in beech ecotypes (Fagus sylvatica L.): phosphorus most affected by

540 Pinno B. D., Landhäusser, S. M., MacKenzie, M. D., Quideau, S. A., and Chow, P. S. 2012. Trembling aspen seedling establishment, growth and response to fertilization on contrasting soils used in oil sands reclamation. Can. J. Soil Sci. 92: 143-151. 
543 Pinno, B. D., and Hawkes, V. C. 2015. Temporal trends of ecosystem on different site types in 544 reclaimed boreal forests. Forests 6: 2109-2124.

545 Portsmuth, A., Niinemets, U., Truus, L., and Pensa, M. 2005. Biomass allocation and growth 546 rates in Pinus sylvestris are interactively modified by nitrogen and phosphorus availabilities and by tree size and age. Can. J. For. Res. 35: 2346-2359.

Qian, P., Schoenau, J. J., and Karamanos, R. E. 1994. Simultaneous extraction of available phosphorus and potassium with a new soil test: a modification of the Kelowna extraction. Commun. Soil Sci. Plant Anal. 25: 627-635.

Rowland, S. M., Prescott, C. E., Grayston, S. J., Quideau, S. A., and Bradfield, G. E. 2009. Recreating a functional forest soil in reclaimed oilsands in northern Alberta: an approach for measuring success in ecological restoration, J. Environ. Qual. 38: 15801590.

Sample, E. C., Soper, R. J., and Racz, G. J. 1980. Reaction of phosphate fertilizer in soil. In The Role of Phosphorus in Agriculture. Edited by F. E. Khasawneh, E. C. Sample and E. J. Kamprath. ASA, CSSA, SSSA, Madison, WI. pp. 263-310.

Simmons, J. A., and Currie, W. S. 2005. Alteration of soil phosphorus pools from coal mining and reclamation. Proc. W. Va. Acad. Sci. 77: 31-41.

Slazak, A., and Freese, D. 2015. Phosphorus sorption kinetics in reclaimed lignite mine soils under different age stands of Robinia pseudoacacia L. in northeast Germany. Appl. Environ. Soil Sci. 2015: 1-19.

Solomon, D., and Lehmann, J. 2000. Loss of phosphorus from soil in semi-arid northern Tanzania as a result of cropping: evidence from sequential extraction and ${ }^{31} \mathrm{P}-\mathrm{NMR}$ spectroscopy. Eur. J. Soil Sci. 51: 699-708. 
566 Sparks, D. L., Page, A. L., Helmke, P. A., and Loeppert, R. H. 1996. Methods of Soil Analysis

567 Part 3 - Chemical Methods. SSSA Book Ser. 5.3. SSSA, ASA, Madison, Wisconsin.

568 Stevenson, F. J. 1986. Cycles of soil carbon, nitrogen, phosphorus, sulfur, micronutrients.

$569 \quad$ Wiley-Interscience, New York.

570 Tessier J. T., and Raynal, D. J. 2003. Use of nitrogen to phosphorus ratios in plant tissue as an

571 indicator of nutrient limitation and nitrogen saturation. J. Appl. Ecol. 40: 523-534.

572 Turner, B. L., Cade-Menun, B. J., Condron, L. M., and Newman, S. 2005. Extraction of soil

$573 \quad$ organic phosphorus. Talanta 66: 294-306.

574 Ung, C. H., Bernier, P., and Guo, X. J. 2008. Canadian national biomass equations: new

575 parameter estimates that include British Columbia data. Can. J. For. Res. 38:

$576 \quad 1123-1132$.

577 Wang, G. G. 1995. White spruce site index in relation to soil, understory vegetation, and foliar 578 nutrients. Can. J. For. Res. 25: 29-38.

579 Weetman, G. F., Yang, R. C., and Bella, I. E. 1985. Nutrition and fertilization of lodgepole 232.

583 Wilde, S. A. 1966. Soil standards for planting Wisconsin conifers. J. For. 64: 389-391.

584 Wood T. E., Bormann, F. H., and Voigt, G. K. 1984. Phosphorus cycling in a northern 585 hardwood forest: biological and chemical control. Science 223: 341-393. 
Table 1. Tree growth, current-year foliar nutrient concentrations and soil properties (means with SD in parentheses) of lodgepole pine and white spruce sites selected for this study in the Athabasca oil sands region, Alberta.

\begin{tabular}{|c|c|c|c|c|}
\hline Parameter & \multicolumn{2}{|c|}{ Pine site } & \multicolumn{2}{|l|}{ Spruce site } \\
\hline Above ground biomass incremen & \multicolumn{2}{|c|}{$4.0(1.1)$} & \multicolumn{2}{|l|}{$2.8(1.0)$} \\
\hline Foliar P ( $\left.\mathrm{mg} \mathrm{g}^{-1}\right)$ & \multicolumn{2}{|c|}{$1.2(0.1)$} & \multicolumn{2}{|l|}{$1.2(0.2)$} \\
\hline Foliar N ( $\left.\mathrm{mg} \mathrm{g}^{-1}\right)$ & \multicolumn{2}{|c|}{$14.2(0.9)$} & \multicolumn{2}{|c|}{$11.1(2.6)$} \\
\hline Foliar N:P ratio & \multicolumn{2}{|c|}{$12.0(0.7)$} & \multicolumn{2}{|l|}{$9.0(2.2)$} \\
\hline Foliar Fe $\left(\mathrm{mg} \mathrm{g}^{-1}\right)$ & \multicolumn{2}{|c|}{$0.12(0.04)$} & \multicolumn{2}{|c|}{$0.11(0.001)$} \\
\hline Foliar $\mathrm{Mn}\left(\mathrm{mg} \mathrm{g}^{-1}\right)$ & \multicolumn{2}{|c|}{$0.07(0.002)$} & \multicolumn{2}{|c|}{$0.05(0.04)$} \\
\hline \multirow[t]{3}{*}{ Foliar Zn $\left(\mathrm{mg} \mathrm{g}^{-1}\right)$} & \multicolumn{2}{|c|}{$0.06(0.002)$} & \multicolumn{2}{|c|}{$0.07(0.01)$} \\
\hline & \multicolumn{2}{|c|}{ Pine site } & \multicolumn{2}{|c|}{ Spruce site } \\
\hline & Peat-mineral soil mix & Tailings sand & Peat-mineral soil mix & Overburden \\
\hline pH (1:2 w:v) & $7.6(0.4)$ & $6.7(0.8)$ & $7.8(0.4)$ & $7.6(0.2)$ \\
\hline Bulk density $\left(\mathrm{Mg} \mathrm{m}^{-3}\right)$ & $0.9(0.3)$ & $1.4(0.2)$ & $0.9(0.3) \mathrm{b}$ & $1.4(0.2) \mathrm{a}$ \\
\hline Organic matter $(\%)$ & $10.7(3.5) \mathrm{a}^{\mathrm{a}}$ & $0.4(0.1) b$ & $11.9(6.5) \mathrm{a}$ & $6.8(0.9) \mathrm{b}$ \\
\hline Clay content $\left(\mathrm{g} \mathrm{kg}^{-1}\right)$ & $230(41)$ & $<\mathrm{DL}^{\mathrm{b}}$ & $300(18)$ & $262(43)$ \\
\hline Electrical conductivity $\left(\mathrm{dS} \mathrm{m}^{-1}\right)$ & $1.0(0.2)$ & $0.2(0.01)$ & $3.9(3.5) \mathrm{a}$ & $0.5(0.2) b$ \\
\hline Available $\mathrm{P}\left(\mathrm{mg} \mathrm{kg}^{-1}\right)$ & $1.9(0.7) \mathrm{a}$ & $0.4(0.1) b$ & $0.8(0.4)$ & $0.5(0.2)$ \\
\hline Total $\mathrm{P}\left(\mathrm{g} \mathrm{kg}^{-1}\right)$ & $0.2(0.6) \mathrm{a}$ & $0.02(0.004) b$ & $0.18(0.1)$ & $0.17(0.05)$ \\
\hline Total N $\left(\mathrm{g} \mathrm{kg}^{-1}\right)$ & $2.5(1.2) \mathrm{a}$ & $0.02(0.01) \mathrm{b}$ & $3.9(2.1) \mathrm{a}$ & $0.5(0.2) \mathrm{b}$ \\
\hline Total C $\left(\mathrm{g} \mathrm{kg}^{-1}\right)$ & $70.3(39.1) \mathrm{a}$ & $1.8(0.7) \mathrm{b}$ & $87.7(67.7)$ & $39.4(5.4)$ \\
\hline $\mathrm{N}: \mathrm{P}$ ratio & $10.5(3.) \mathrm{a}$ & $1.4(0.9) \mathrm{b}$ & $26.2(21.1)$ & $3.29(1.5)$ \\
\hline $\mathrm{C}: \mathrm{P}$ ratio & $302.7(132.3) \mathrm{a}$ & $113.3(38.1) \mathrm{b}$ & $586.1(302.1)$ & $255.7(65.5)$ \\
\hline $\mathrm{C}: \mathrm{N}$ ratio & $28.1(8.1) \mathrm{b}$ & $100.4(77.3) \mathrm{a}$ & $31.1(24.2)$ & $87.2(27.3)$ \\
\hline $\mathrm{Ca}_{\mathrm{M}}{ }^{\mathrm{c}}\left(\mathrm{mg} \mathrm{kg}^{-1}\right)$ & $253.1(20.8) \mathrm{a}$ & $11.6(4.0) \mathrm{b}$ & $519.6(237.8)$ & $218.1(25.1)$ \\
\hline $\operatorname{Mg}_{M}{ }^{c}\left(\mathrm{mg} \mathrm{kg}^{-1}\right)$ & $48.5(7.0) \mathrm{a}$ & $2.7(0.7) b$ & $58.6(15.5)$ & $47.4(13.5)$ \\
\hline $\mathrm{Al}_{\mathrm{M}}^{\mathrm{c}}\left(\mathrm{mg} \mathrm{kg}^{-1}\right)$ & $3.9(3.7) \mathrm{a}$ & $1.1(0.1) b$ & $0.7(0.4) b$ & $3.1(2.0) \mathrm{a}$ \\
\hline $\mathrm{Fe}_{\mathrm{M}}{ }^{\mathrm{c}}\left(\mathrm{mg} \mathrm{kg}^{-1}\right)$ & $26.3(3.8) \mathrm{a}$ & $6.4(1.3) b$ & $22.5(17.5)$ & $20.0(4.7)$ \\
\hline
\end{tabular}


Different letters indicate significant differences in soil properties between PMM and substrate within each site type at $\mathrm{p}<0.05(\mathrm{n}=6)$

${ }^{\mathrm{b}} \mathrm{DL}$ stands for detection limit.

${ }^{\mathrm{c}} \mathrm{Ca}_{\mathrm{M}}, \mathrm{Mg}_{\mathrm{M}}, \mathrm{Al}_{\mathrm{M}}$ and $\mathrm{Fe}_{\mathrm{M}}$ indicate Mehlich-3 extractable $\mathrm{Ca}, \mathrm{Mg}, \mathrm{Al}$ and $\mathrm{Fe}$, respectively. 
Table 2. Pearson correlation coefficients and significance levels for correlations among foliar P concentration, P fractions and soil properties of peat-mineral soil mix in lodgepole pine and white spruce sites.

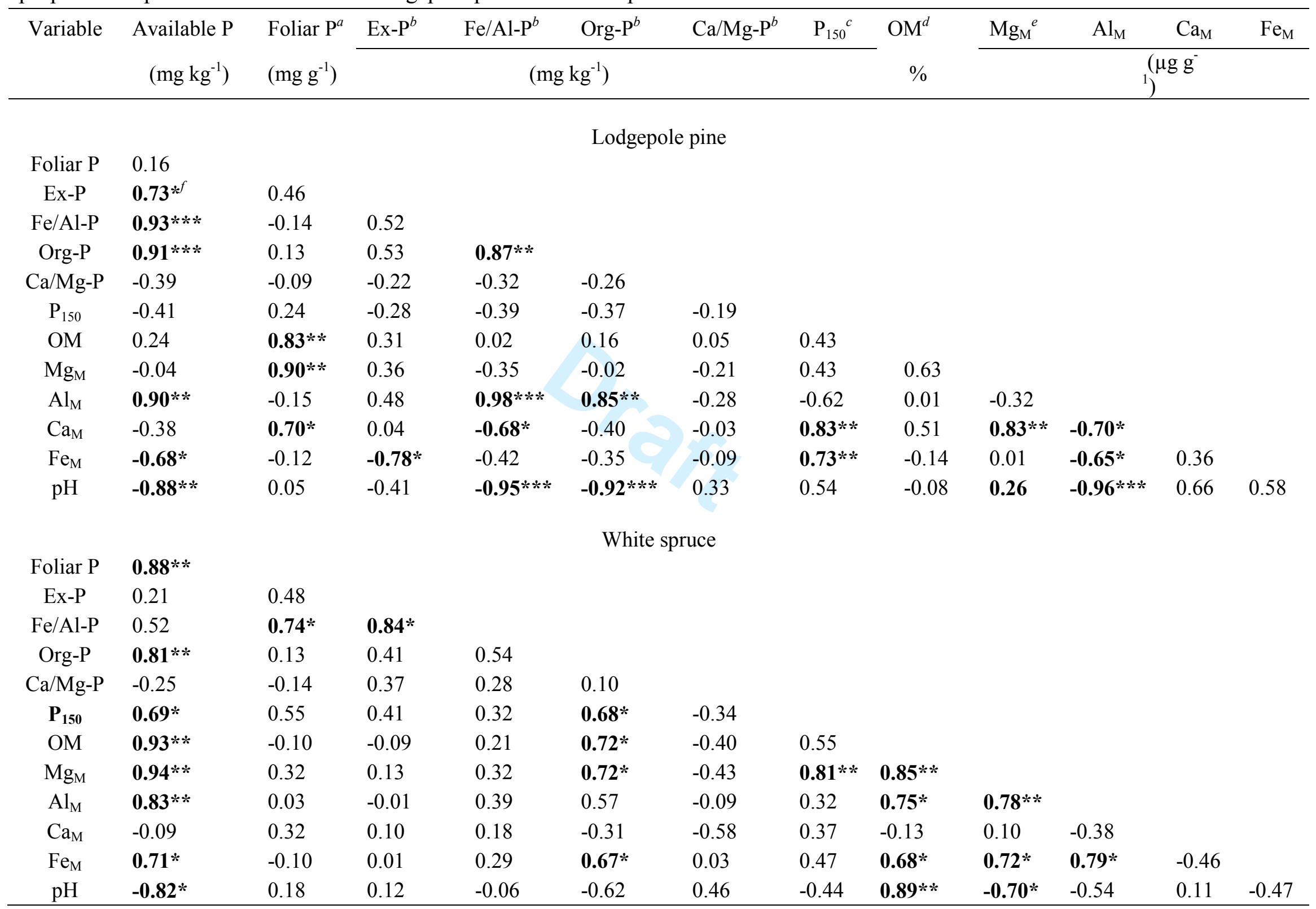


${ }^{a}$ Foliar $\mathrm{P}$ concentration in current-year needles.

${ }^{b}$ Ex-P, Fe/Al-P, Org-P and $\mathrm{Ca} / \mathrm{Mg}-\mathrm{P}$ represent exchangeable $\mathrm{P}, \mathrm{P}$ associated with $\mathrm{Fe}$ and $\mathrm{Al}$, organically bound $\mathrm{P}$ and $\mathrm{P}$ associated with $\mathrm{Ca}$ and $\mathrm{Mg}$, respectively.

${ }^{c} \mathrm{P}_{150}$ represents the adsorption maxima determined using a one-point $\mathrm{P}$ sorption isotherm conducted at $150 \mathrm{mg} \mathrm{P} \mathrm{L}$.

${ }^{d} \mathrm{OM}$ stands for organic matter content.

${ }^{e}$ Cations with subscript M denote Mehlich III extractable cations. ${ }^{f *}, * *$ and $* * *$ indicate $p<0.05, p<0.01$ and $p<0.001$, respectively. 
Table 3. Pearson correlation coefficients between current above ground biomass increment and soil and current-year foliar P data of white spruce sites. ( $p$ values are given in parentheses).

\begin{tabular}{|c|c|c|c|c|c|c|}
\hline & $\begin{array}{l}\text { Available P } \\
\left(\mathrm{mg} \mathrm{kg}^{-1}\right)\end{array}$ & $\begin{array}{l}\text { Soil } \\
C: P\end{array}$ & $\begin{array}{l}\text { Foliar P } \\
\left(\mathrm{mg} \mathrm{g}^{-1}\right)\end{array}$ & $\begin{array}{l}\text { Foliar } \\
\mathrm{P}: \mathrm{Fe}\end{array}$ & $\begin{array}{l}\text { Foliar } \\
\text { P:Mn }\end{array}$ & $\begin{array}{c}\text { Foliar } \\
\mathrm{P}: \mathrm{Zn}\end{array}$ \\
\hline $\begin{array}{l}\text { Aboveground } \\
\text { biomass } \\
\text { increment } \\
\left(\mathrm{Mg} \mathrm{ha}^{-1} \mathrm{yr}^{-1}\right)\end{array}$ & $\begin{array}{c}0.71 \\
(0.03)\end{array}$ & $\begin{array}{c}0.65 \\
(0.05)\end{array}$ & $\begin{array}{c}0.59 \\
(0.06)\end{array}$ & $\begin{array}{c}0.77 \\
(0.01)\end{array}$ & $\begin{array}{c}0.84 \\
(0.01)\end{array}$ & $\begin{array}{c}0.78 \\
(0.01)\end{array}$ \\
\hline
\end{tabular}


a Pine sites
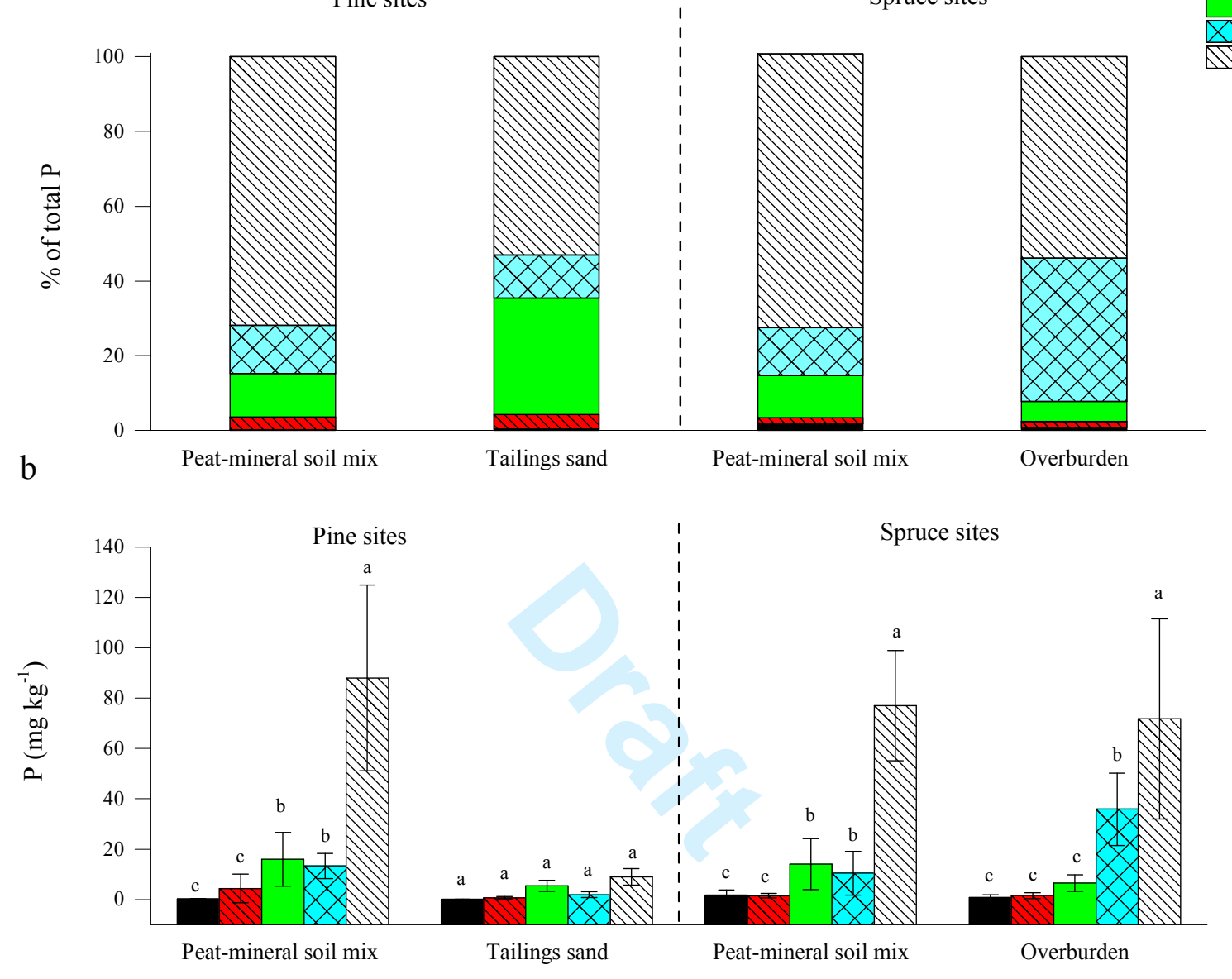

Fig. 1. Distribution of various forms of $P$ (a) expressed as a percent of the total $P$ and (b) absolute concentration of $\mathrm{P}$ forms in peat-mineral soil mix and substrate in lodgepole pine and white spruce sites. Ex-P, exchangeable P; Fe/Al-P, P associated with Fe and Al oxides; Org-P, organically bound $\mathrm{P} ; \mathrm{Ca} / \mathrm{Mg}-\mathrm{P}, \mathrm{Ca}$ and $\mathrm{Mg}$-associated $\mathrm{P}$. Vertical error bars in (b) indicate standard deviations and different letters indicate significant differences among the concentration of $\mathrm{P}$ forms in each soil layer at $\mathrm{p}<0.05$. 


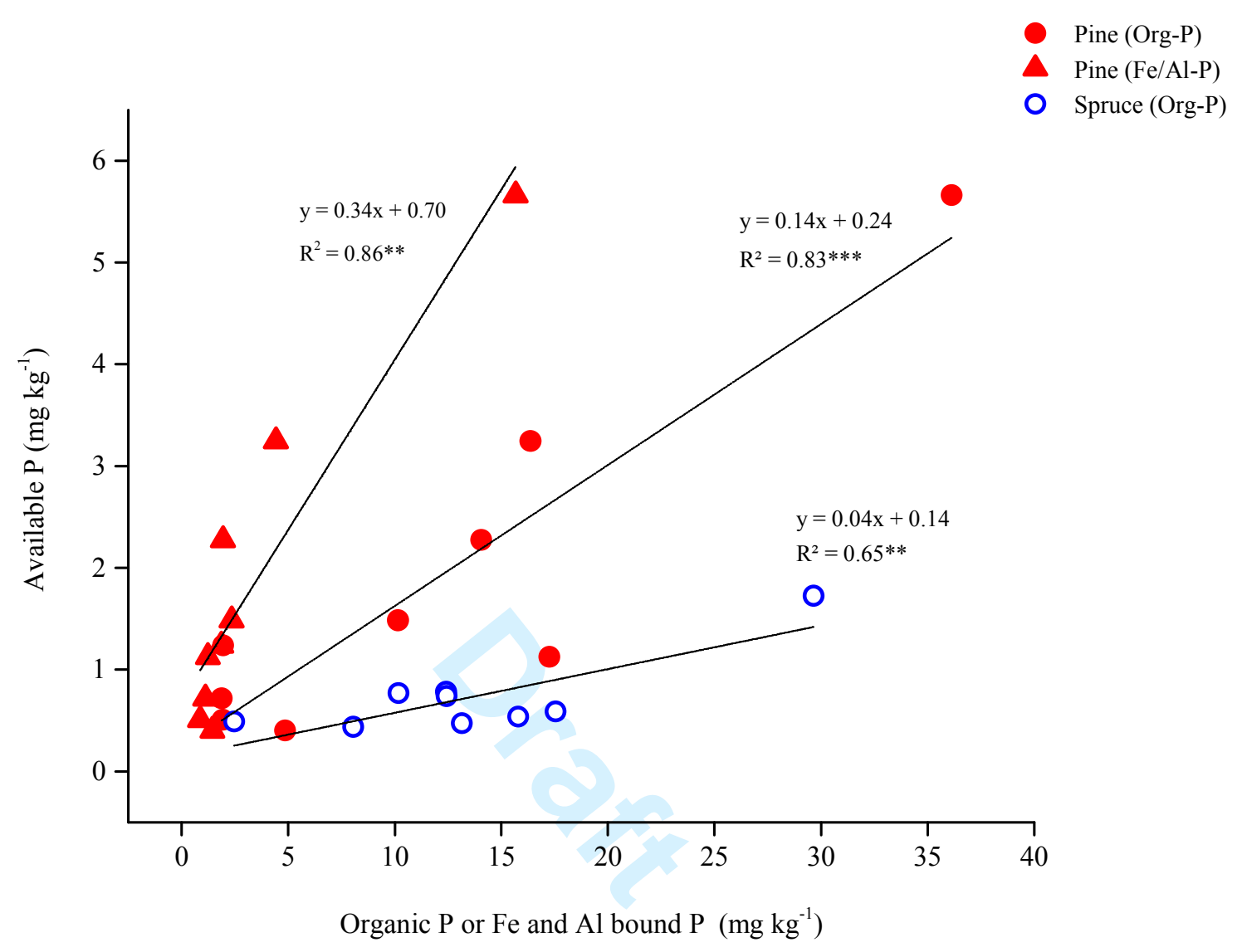

Fig. 2. Relationships between available $\mathrm{P}$ and organic or Fe and $\mathrm{Al}$ bound $\mathrm{P}$ fractions in peatmineral soil mix in lodgepole pine and white spruce sites. The asterisks indicate the significance of the regression lines, with $* *$ and $* * *$ indicating $p<0.01$ and $p<0.001$, respectively. 

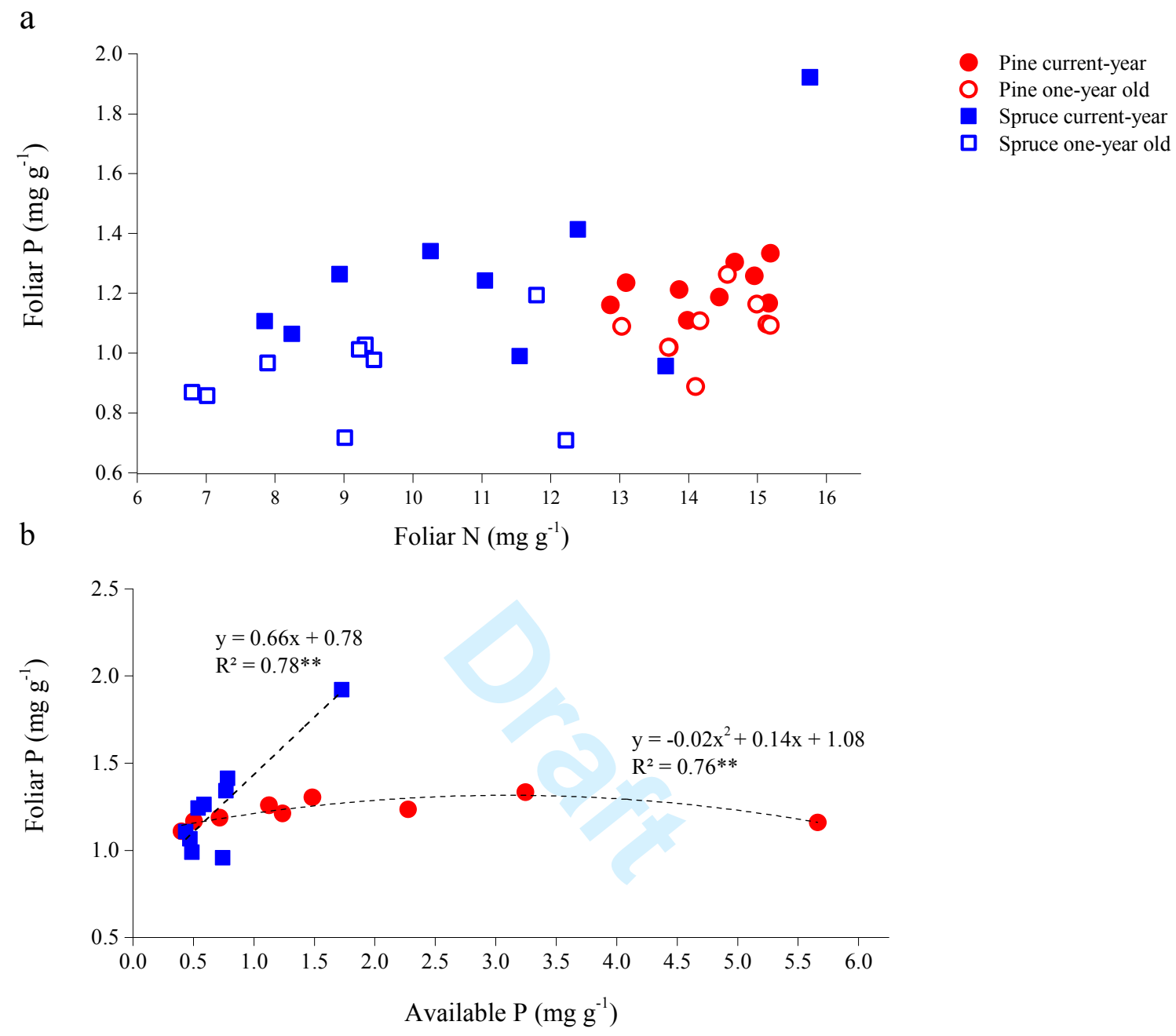

Fig. 3. Relationship between (a) foliar N and P concentrations in current-year and one-year-old needles in lodgepole pine and white spruce, and (b) available P concentration in PMM and foliar $\mathrm{P}$ concentration in current-year needles in lodgepole pine and white spruce sites. The asterisks indicate the significance of the regression lines at $p<0.01$ 
Phosphorus availability and fractionation vary among forest site types in reconstructed oil sands soils

Mihiri C.W. Manimel Wadu, Min Duan, Scott X. Chang

Supplementary Materials

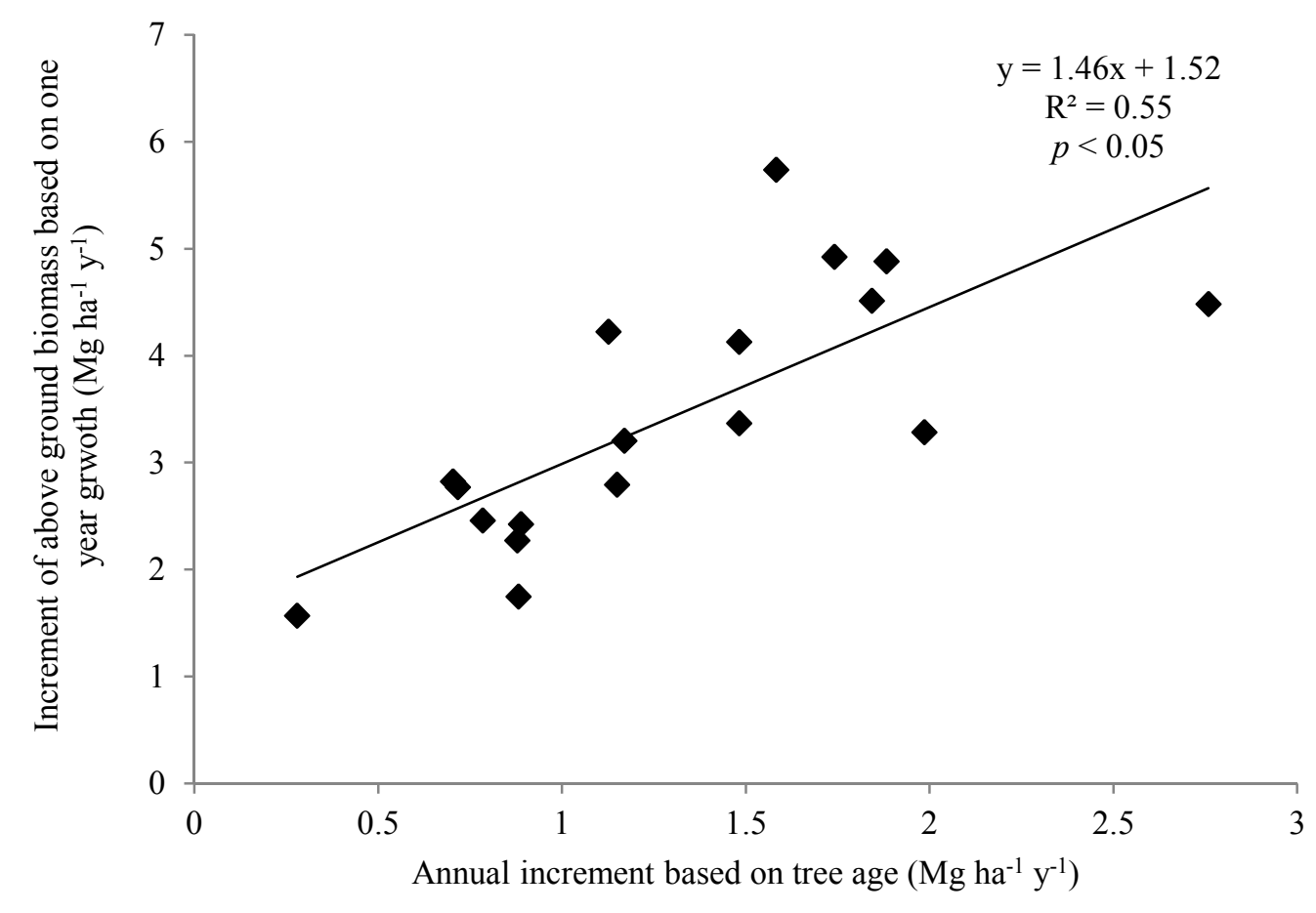

S1. Relationship between increment of aboveground biomass based on one year growth measurement and mean annual increment based on total biomass and tree age for lodgepole pine and white spruce. 


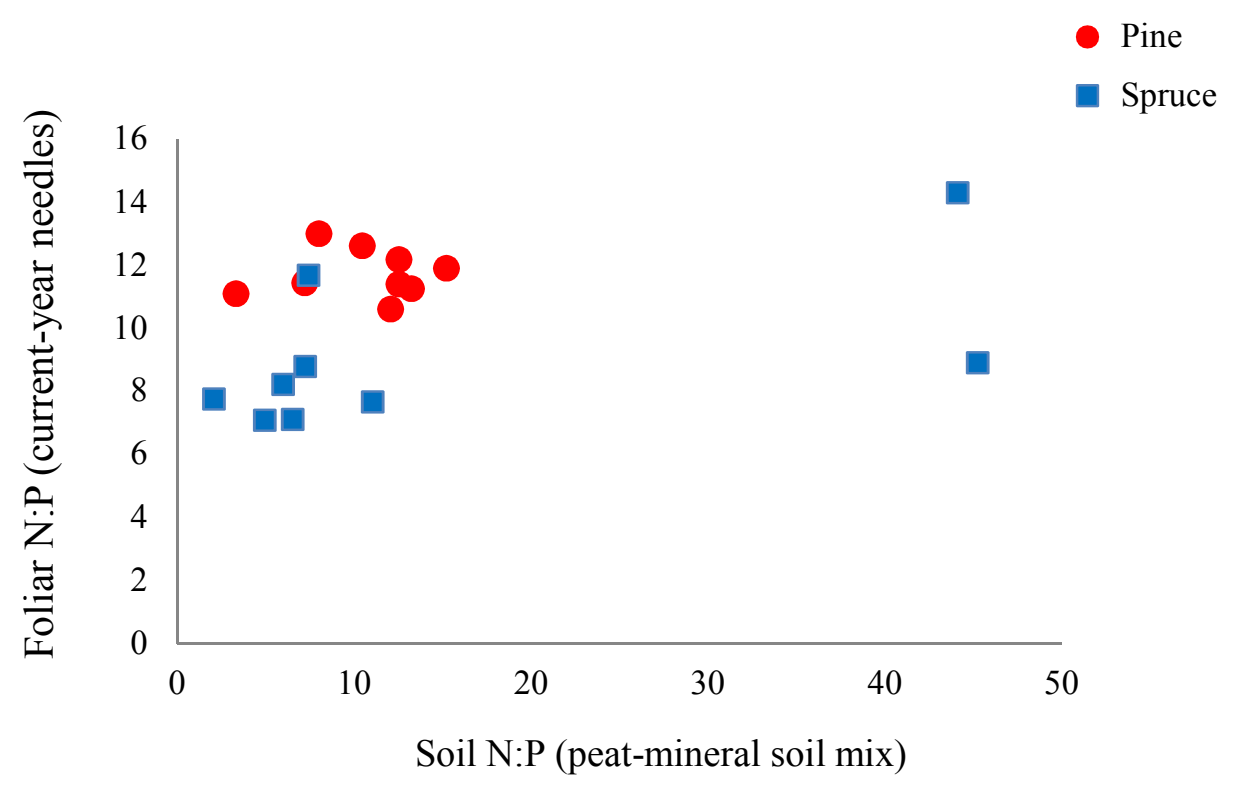

S2. Relationship between foliar and soil N:P ratios of lodgepole pine and white spruce sites. 
S3. Pearson correlation coefficients among aboveground biomass increment, foliar $\mathrm{P}$ concentration (current-year needle), available $\mathrm{P}$ and $\mathrm{P}$ fractions in tailings sand in lodgepole pine sites. Bold values are $\mathrm{p}$ values.

Tailings sand

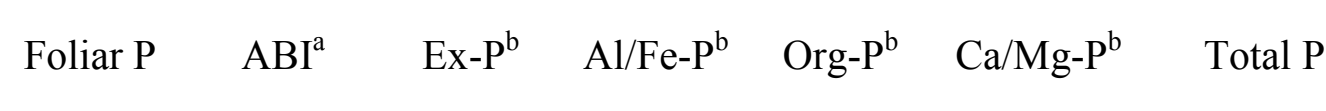

Available P

0.03

$-0.28$

$-0.03$

0.31

$-0.13$

0.4

0.12

Foliar P

0.93

0.46

0.95

0.41

0.74

0.28

0.75

0.34

$-0.02$

$-0.22$

0.56

0.23

0.03

$\mathbf{0 . 3 7}$

0.96

0.56

0.12

0.54

0.93

$\mathrm{ABI}^{\mathrm{a}}$

0.11

0.05

0.54

$-0.3$

0.13

0.77

0.91

0.13

0.43

0.74

Peat-mineral soil mix

\begin{tabular}{cccccccc} 
& Foliar $\mathrm{P}$ & $\begin{array}{c}\text { Available } \\
\mathrm{P}\end{array}$ & ${\text { Ex }-\mathrm{P}^{\mathrm{b}}}$ & $\mathrm{Al} / \mathrm{Fe}-\mathrm{P}^{\mathrm{b}}$ & Org- $^{\mathrm{b}}$ & $\mathrm{Ca} / \mathrm{Mg}-\mathrm{P}^{\mathrm{b}}$ & Total P $^{\mathrm{A}} \mathrm{ABI}^{\mathrm{a}}$ \\
\cline { 2 - 7 } & 0.05 & 0.34 & 0.23 & -0.14 & -0.20 & -0.67 & 0.11 \\
& $\mathbf{0 . 0 9}$ & $\mathbf{0 3 7}$ & $\mathbf{0 . 5 5}$ & $\mathbf{0 . 7 1}$ & $\mathbf{0 . 6 7}$ & $\mathbf{0 . 0 4}$ & $\mathbf{0 . 7 9}$ \\
\hline
\end{tabular}

${ }^{a}$ Aboveground biomass increment.

${ }^{b}$ Ex-P, Fe/Al-P, Org-P and Ca/Mg-P represent exchangeable P, P associated with Fe and $\mathrm{Al}$, organically bound $\mathrm{P}$, and $\mathrm{P}$ associated with $\mathrm{Ca}$ and $\mathrm{Mg}$, respectively. 
S4. Pearson correlation coefficients among aboveground biomass increment, foliar P concentration (current-year needle), available $\mathrm{P}$ and $\mathrm{P}$ fractions in overburden in white spruce sites. Bold numbers are $p$ values.

\begin{tabular}{|c|c|c|c|c|c|c|c|}
\hline & Foliar P & $\mathrm{ABI}^{\mathrm{a}}$ & $E x-P^{b}$ & $\mathrm{Al} / \mathrm{Fe} \mathrm{P}^{\mathrm{b}}$ & Org- $\mathrm{P}^{\mathrm{b}}$ & $\mathrm{Ca} / \mathrm{Mg}-\mathrm{P}^{\mathrm{e}}$ & bTotal P \\
\hline \multirow[t]{2}{*}{ Available P } & 0.21 & -0.39 & 0.34 & 0.69 & 0.86 & 0.22 & 0.53 \\
\hline & 0.58 & 0.30 & 0.38 & 0.04 & $<0.01$ & 0.58 & 0.14 \\
\hline \multirow[t]{2}{*}{ Foliar P } & & 0.60 & 0.14 & 0.51 & 0.40 & 0.59 & 0.28 \\
\hline & & 0.09 & 0.71 & 0.16 & 0.29 & 0.10 & 0.47 \\
\hline \multirow[t]{2}{*}{$\mathrm{ABI}$} & & & -0.07 & -0.24 & -0.29 & 0.19 & 0.00 \\
\hline & & & 0.86 & 0.54 & 0.46 & 0.62 & 1.00 \\
\hline
\end{tabular}

${ }^{a}$ Aboveground biomass increment.

${ }^{b}$ Ex-P, Fe/Al-P, Org-P and $\mathrm{Ca} / \mathrm{Mg}-\mathrm{P}$ represent exchangeable $\mathrm{P}, \mathrm{P}$ associated with $\mathrm{Fe}$ and $\mathrm{Al}$, organically bound $\mathrm{P}$, and $\mathrm{P}$ associated with $\mathrm{Ca}$ and $\mathrm{Mg}$, respectively. 